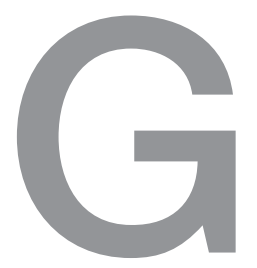

German
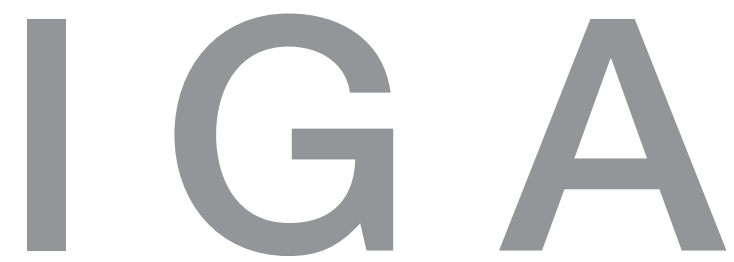

Working Papers

GIGA Research Programme:

Violence and Security

Iran's Oil Wealth:

Treasure and Trouble for the Shah's Regime

A Context-sensitive Analysis of the Ambivalent Impact of Resource Abundance

Miriam Shabafrouz

No 113

November 2009 


\section{GIGA Working Papers}

Edited by the

GIGA German Institute of Global and Area Studies

Leibniz-Institut für Globale und Regionale Studien

The GIGA Working Papers series serves to disseminate the research results of work in progress prior to publication in order to encourage the exchange of ideas and academic debate. An objective of the series is to get the findings out quickly, even if the presentations are less than fully polished. Inclusion of a paper in the GIGA Working Papers series does not constitute publication and should not limit publication in any other venue. Copyright remains with the authors. When working papers are eventually accepted by or published in a journal or book, the correct citation reference and, if possible, the corresponding link will then be included on the GIGA Working Papers website at <www.giga-hamburg.de/ workingpapers>.

GIGA research unit responsible for this issue:

Research Programme "Violence and Security"

Editor of the GIGA Working Papers series: Martin Beck <beck@giga-hamburg.de>

Copyright for this issue: (C) Miriam Shabafrouz

English copy editor: Melissa Nelson

Editorial assistant and production: Christine Berg

All GIGA Working Papers are available online and free of charge on the website $<w w w$. giga-hamburg.de/workingpapers $>$. They can also be ordered in print. A fee of $€ 5$ will be charged for production and postage costs. For orders or any requests please contact:

E-mail: workingpapers@giga-hamburg.de

Phone: ++49 (0)40 - 42825 - 548

The GIGA German Institute of Global and Area Studies cannot be held responsible for errors or any consequences arising from the use of information contained in this Working Paper; the views and opinions expressed are solely those of the author or authors and do not necessarily reflect those of the Institute.

GIGA German Institute of Global and Area Studies

Leibniz-Institut für Globale und Regionale Studien

Neuer Jungfernstieg 21

20354 Hamburg

Germany

E-mail: info@giga-hamburg.de

Website: www.giga-hamburg.de 


\title{
Iran's Oil Wealth: Treasure and Trouble for the Shah's Regime A Context-sensitive Analysis of the Ambivalent Impact of Resource Abundance
}

\begin{abstract}
The Iranian revolution still appears to be a puzzle for theoretical approaches linking political instability and/or violent conflict to the resource wealth of a country. It therefore works well as a case study for the purposes of this paper: to show the necessity of a broader approach to the resource-violence link and to highlight the "context approach." The focus is on the violence that accompanied the events preceding the revolution, and also on the fact that this violence was mainly exercised by the rulers and-excluding the activities of militant groups-only very randomly by the masses. Many relevant contextual conditions had an impact on the downfall of the shah's regime: demographic (population growth, urbanization) and cultural factors (religious tradition, national identity); the vivid memory of several historical events; the personal preferences of central actorsmainly both the shahs - which in combination brought the country to an impasse; and the religious opposition to the regime. But upon closer examination, it becomes clear that many of those factors were influenced by resource-specific conditions such as the amount and the use of oil income, sudden oil-price drops, and external interference aimed mainly at the domination of the oil sector. It was the specific interplay of these and other contextual conditions - as much resource-specific as general, and both within the country and on an international scale-that finally brought about the downfall of the regime.
\end{abstract}

Keywords: Iran, oil, revolution, resource curse, rentier state theory, context approach

\section{Dipl.-Sowi. Miriam Shabafrouz}

is a political scientist and research fellow at the German Institute of Global and Area Studies (GIGA). She is currently working on the German Research Foundation (DFG)-financed project "Is Resource Wealth a Risk Factor? On the Importance of Contextual Conditions for the Connection Between Natural Resources and Violence in Non-OECD States" under the direction of Dr. Matthias Basedau.

Contact: shabafrouz@giga-hamburg.de

Website: http://staff.giga-hamburg.de/shabafrouz 


\section{Zusammenfassung}

\section{Irans Ölreichtum: Stolz und Stolperstein für das Schahregime}

Eine kontextsensible Analyse der ambivalenten Auswirkungen von

\section{Ressourcenreichtum}

Die iranische Revolution ist heute noch ein Rätsel für theoretische Ansätze, die politische Instabilität und/oder gewaltsame Konflikte auf den Ressourcenreichtum eines Landes zurückführen. An ihr wird die Notwendigkeit deutlich, die Verbindung zwischen Ressourcenreichtum und Gewalt in einem größeren Kontext zu sehen. Der Fokus des Artikels liegt auf der Gewalt, die die Ereignisse vor der Revolution begleitete. Mehrere Kontextbedingungen waren dabei relevant, wie zum Beispiel demografische (Bevölkerungswachstum, Urbanisierung) und kulturelle Faktoren (religiöse Traditionen, nationale Identität). Auch die kollektive Erinnerung an bestimmte historische Ereignisse und die persönlichen Präferenzen zentraler Akteure - und hier vor allem beider Schahs - haben in ihrem spezifischen Zusammenspiel das Land in eine Sackgasse und die religiöse Opposition an die Macht geführt. Die Untersuchung verdeutlicht, dass viele dieser Faktoren durch ressourcenspezifische Bedingungen beeinflusst wurden, wie z. B. die Menge und die Verwendung der Erdöleinnahmen, plötzliche Erdölpreissenkungen oder auch Einflussnahmen durch externe Akteure, die vor allem auf die Kontrolle des Erdölsektors abzielten. Es war das spezifische Zusammenspiel sowohl ressourcen-spezifischer als auch allgemeiner Kontextbedingungen, innerhalb und außerhalb des Landes, die schlussendlich den Zusammenbruch des Regimes herbei führten und zur Gewaltanwendung beitrugen. 


\title{
Iran's Oil Wealth: Treasure and Trouble for the Shah's Regime A Context-sensitive Analysis of the Ambivalent Impact of Resource Abundance
}

\author{
Miriam Shabafrouz
}

\author{
Article Outline \\ 1 Introduction \\ 2 The Conceptualization of Oil Wealth and Violence and Their Relation \\ 3 The Link between Oil Wealth and Violence and the Context Approach \\ 4 Context and Causality in the Case of the Islamic Revolution \\ 5 Summary and Conclusion
}

\section{Introduction}

Oil is often considered to be a dangerous raw material, both in a political and an economic sense. A growing number of scientific studies have seized upon this topic and presume that a wealth of or a dependence on precious natural resources has far-reaching impacts for a country. While the "resource curse" approach sees a link between oil wealth and violence (Collier/Hoeffler 1998; Ross 2004), the rentier state theory predicts, in contrast, a significant likelihood of state stability (Beblawi/Luciani 1987; Karl 1997). Although they have a similar focus-resource abundance ${ }^{1}$ - these two theoretical approaches are not entirely compatible

1 Or, to be more precise, the dependence on revenue accruing from the resource sector, something which is often not explicitly differentiated. 
(Basedau 2005), and both share the tendency to neglect the fact that the very same problems, authoritarianism and violent conflict, also occur in states without any resource wealth. There are, furthermore, resource-rich states which do not have the predicted problems (such as Botswana, Chile, and Norway). And finally, some events and developments in resourcewealthy countries fall outside of the theoretical expectations, which could reveal serious weaknesses in both approaches. For this reason, it is not only interesting but also necessary to take a closer look at the mechanisms governing political problems, particularly the phenomenon of violence, in a number of oil-exporting countries. The research project proposes a refinement of the two theories above, following the assumption that "context matters" (ibid.) in the occurrence of violence and thereby including a broader internal and external context. This paper, which is part of a series of four case studies, ${ }^{2}$ offers an analysis of one of the world's leading oil-exporting countries: Iran. While the rentier state theory largely seems to apply to this country, under both the monarchical and the Islamic regime (Najmabadi 1987, Beck 2007: 53), there are events in its history which cannot be explained with this theory, such as the Islamic Revolution (Beck 2007: 53). ${ }^{3}$ This prominent turning point makes Iran a challenging case for this theory - at least at the very moment it happened.

The aim of this study is to determine to what extent the Islamic Revolution, and particularly the violence that accompanied it, can be explained by the country's oil wealth. Can (1) the conventional theoretical approaches (rentier state, resource curse) explain the occurrence of violence (or its absence) during the Iranian Revolution? And (2) which contextual conditions may provide an alternative explanation? Are some observable forms of violence independent from resource wealth? Do some conditions reinforce or weaken the effects of resource wealth on violence?

The study will show not only that a combination of many contextual conditions enabled or caused the revolution to happen, but also that the impact of the resource-specific conditions should not be underestimated. On the one hand, the paper will analyze how fatal the dependency on oil was for the economic and political stability of the regime. On the other hand, it will look at how variations on the world's oil market and in the power constellations

2 The German Research Foundation (DFG)-financed project “Is Resource Wealth a Risk Factor? On the Importance of Contextual Conditions for the Connection Between Natural Resources and Violence in Non-OECD States," under the direction of Dr. Matthias Basedau from the GIGA German Institute of Global and Area Studies undertakes a comparative analysis of four country cases: Iran, Venezuela, Algeria and Nigeria. These countries have been chosen for the similarities in some of their basic resource-specific conditions (oil, degree of dependence and abundance per capita, and having the first or second most important reserves in their respective region), and their clear divergences concerning the intensity and dynamics of physical violence. The project also comprises a large- $\mathrm{N}$ study using quantitative methods for measuring the impact of contextual conditions.

3 It was a deliberate decision to exclude the vast academic literature on revolutions (for instance Skocpol 1979) within the theoretical framework in order to be able to concentrate on approaches focusing on the impact of natural resources on violence. 
in other countries-as new research results demonstrate-significantly contributed to the downfall of the shah's regime.

This paper proceeds as follows: Before entering into the empirical analysis, it is necessary to define, in the first section, the independent and dependent variables (oil wealth and violence) and to outline their significance in the case of Iran. In the second section, the discussion briefly explores the proposals of different theories in order to understand the links between them. Subsequently, I propose in Section 3 to refine these theoretical approaches with contextual variables and to establish an extended explanatory model based on the context approach (Basedau 2005) with hypotheses about causal mechanisms leading to or preventing physical violence. In the fourth section, I then analyze the Iranian Revolution (focusing in particular on violence) according to the contextual pattern, giving special regard to the interplay of the contextual conditions. Finally, I attempt to answer the above questions.

\section{The Conceptualization of Oil Wealth and Violence and Their Relation}

It is reasonable to assume that a substantial income deriving from significant oil stocks will affect the economy, society, domestic policy, and the international relations of a country, all of which can in turn impact the level of violence. But opinions differ as to what these effects look like and how they operate. This is particularly the case for the link between oil wealth (the independent variable here) and violence (the dependent variable). Before examining this link in the case of Iran, it is necessary to define the variables and to provide a sense of their dimensions in the country.

\subsection{The Independent Variable: Oil Wealth}

In examining the oil wealth of a country, it is important to distinguish between external and internal wealth, which have very different implications (Basedau/Lay 2009). External oil wealth is basically a relational quality, insofar as an oil-wealthy country is considered to have relatively more stocks than other countries. It should not be confused with oil dependency (Le Billon 2001, de Soysa 2002: 405), as is frequently the case: often, the percentage of the gross domestic product (GDP) or export income deriving from the oil sector is taken as a proxy for oil abundance, but at second glance it becomes clear that this indicator is not appropriate (Basedau 2005, Brunnschweiler/Bulte 2006; Basedau/Lay 2009). It is much more a sign that other incomes are low than of actual or potential wealth (Herb 2005, Brunnschweiler/Bulte 2006). It does not express the actual amount of income, and it definitely does not take into account the relative wealth of countries (Basedau/Lacher 2006: 8). Basedau (2005: 25) therefore proposes measuring the income from the resource sector in per capita terms in order to obtain a more realistic picture of actual abundance or scarcity. This measure can be considered as a measure of internal wealth. As has been shown by Basedau and Lay, countries 
which are oil wealthy in per capita terms are not prone to violent conflict (Basedau/Lay 2009). Brunnschweiler and Bulte (2006) further advocate using a stock measure of in situ resource wealth as a proxy for abundance; this makes a comparison with other countries possible and thus aids in determining the relative abundance of a resource.

Iran can without question be defined as an oil-wealthy country in terms of its stocks and its export rate. With the second-largest share of all proven reserves of oil (11 percent) and gas (16 percent) in the world to date and with the fourth-largest amount of oil exports per day (BP-dataset 2007), Iran is today-and will very probably remain-one of the world's most important energy suppliers. The entire Middle East region is of great relevance in this respect since one-third of the world's oil comes from the countries bordering the Persian Gulf and more than 60 percent of the stocks are located on this subcontinent. With the gradual depletion of the oil fields in the North Sea and in North America, the region will very probably even gain in importance. But the simple consideration of oil wealth as such does not go far in terms of understanding internal dynamics. Therefore, I will differentiate this wealth by adding the different aspects of dependence, the domestic and international distribution of resources, and resource-sector management-which are considered to be resource-specific contextual conditions - to the analysis.

\subsection{The Dependent Variable: Violence}

The dependent variable in this analysis comprises any form of physical violence used to obtain or maintain political power and/or access to oil money in resource-wealthy countries, such as mass conflicts (civil wars, armed conflicts and interstate wars); violent unrest below the threshold of mass conflicts; (attempted) coups; violence linked to revolts and revolutions; terrorist attacks; and finally, violent human rights violations by the government. ${ }^{4}$ The different forms of violence can be further distinguished according to their frequency, duration, intensity, and dynamics. Several institutes, such as the Uppsala Conflict Data Program (UCDP) together with the International Peace Research Institute, Oslo (PRIO), the Correlates of War Project and the Heidelberg Institute for International Conflict Research (HIIK), have already collected some useful information and data in this respect and can provide a first indication. Still, their concentration on the number of battle deaths and/or overall duration of conflicts is not fully appropriate for a case study. A thorough understanding of the causes of violent incidents and their dynamics requires more detailed data that also include a qualitative assessment of historical developments.

4 This is a deliberately narrower definition than, for instance, the notions of "structural violence" (Galtung 1975) or "human security" (UNDP 1994), as the latter make the analysis of clear causal mechanisms for this paper's purposes almost impossible. Some elements of broader conceptions of violence, such as economic, social and political disparities, shall be considered as relevant factors contributing to the occurrence of physical violence and are therefore included in the contextual conditions. 
Relevant for the underlying question regarding the link between resource wealth and violence seem to be four periods in Iran between the first oil shock in 1973 and 2007, each of which was characterized by a different form of violence. ${ }^{5}$ They all deserve a closer look from a theoretical perspective which measures the impact of oil on the level of violence and weighs it using the "context approach." For the following analysis, it was considered reasonable to focus on the Islamic Revolution, as this case is the one assumed here to challenge the rentier state theory. It should be emphasized, however, that it is not the aim of this paper to falsify this theory, but rather to demonstrate the necessity of including a broader range of variables in the analysis of so-called rentier states in order to understand the mechanisms leading to or preventing violence. The level of violence linked to coups and revolutions in general and in this particular case is not necessarily high, but there were violent incidents that could be observed in Iran during the revolution. These included the repressive measures of the security forces on the one hand and the terrorist attacks of militant groups such as the Mojahedeen-e Khalq on the other. However, what was remarkable was the low level of violence from the side of the opposition and the masses, which ultimately brought about the collapse of an entire regime.

\section{The Link between Oil Wealth and Violence and the Context Approach}

Starting with a brief presentation of the approaches conventionally used for the analysis of resource-wealthy and/or dependent states (3.1), I will now detail the context approach (3.2), which guides the subsequent analysis.

\subsection{Resource Curse and Rentier State}

The assumptions of the resource curse approach can be useful in analyzing the general pattern of conflicts in oil-wealthy countries. Basically, it expects that resource wealth has a negative impact on economic development and political stability (Auty 1993; Sachs/Warner 1995, 2001; Karl 1997) and considerably raises the risk of conflict in a given country (Collier/Hoeffler 1998, 2001, 2002, 2004; Ross 2004, 2006; de Soysa 2008 and others). The resources have this effect by providing, on the one hand, the motive for rebels to attempt to gain power and for the rulers to defend their position and, on the other, the opportunity for the outbreak of armed conflicts, as they are an important source of financing for violent activities, both for rebels and the state (Collier/Hoeffler 2004: 564). More recent analyses distinguish between the types of resource and also between modes of redistributing the resource revenue (Le Bil-

5 These are (1) the Islamic Revolution, (2) the oppression of regime opponents under the shah and the Islamic Republic, (3) the Iran-Iraq War, and (4) ethnic unrest in the border regions. The first reason for this selection is the diversity of types of violence, which can be analyzed in the light of the different theories and which allows the development of new proposals. The second reason is their prominent role in the country's recent history. 
lon 2001, Boschini et al. 2007). Oil is considered to make the onset of conflict more likely (Ross 2004). It is not easily "lootable," given the high technical and infrastructural prerequisites for oil production, but it can heighten interest on the side of other states or powerful groups within the country in challenging the central power. Further, it is assumed that resource wealth can indirectly raise the probability of violence (de Soysa/Neumayer 2007) via its other effects, such as economic deformations, corruption, bad governance, low institutional quality (Boschini et al. 2007), a lack of democracy, and human rights violations.

Many elements of the resource curse approach - its basic assumptions, the methodology of the analysis, its conclusions - have been criticized (see for instance Ross 2004; Smith 2004; Nathan 2005; Brunnschweiler/Bulte 2006; Rosser 2006; Di John 2007). As a response, some new elements have already been incorporated into the basic approach, such as the previously mentioned distinction between several features of resources, such as dependence, location and mode of extraction. This is already a step towards integrating contextual conditions into the theoretical framework.

Still, the relatively low level of rebel activities in Iran before and after the revolutioncompared, for example, to oil-rich states in Africa such as Nigeria or Sudan-and the relatively high regime stability of the oil-exporting countries in North Africa and the Persian Gulf region does not seem to confirm the explanatory power of this theory. This could be related to the high per capita income from the resource sector in some of these states. As Basedau and Lay (forthcoming) have determined, a high level of resource wealth actually decreases the likelihood of violence. Smith (2004) even comes to the conclusion that regime stability is generally quite high in oil-exporting states. This could be an argument in favor of the rentier state theory, as shall be explored in the following subsection. ${ }^{6}$

For many scholars, the rentier state theory is the favored approach for the analysis of oil-rich states in the Persian Gulf region, North Africa, and elsewhere. Interestingly, Iran was the country for which the theory was developed in the first place (Mahdavy 1970). The theory focuses on oil dependence rather than oil wealth when defining states with a high share of rents in their national income-that is, revenues such as resource rents and development aid, obtained without productive activities and mainly accruing from abroad-as rentier states. The main assumption is that these states tend to be more inefficient economically than states with a more diversified economy and a budget based on tax extraction on the one hand, and more authoritarian politically on the other (Beck 2007: 45). The theory postulates that the governments of rentier states frequently use the money accruing from the resource sector to buy off the opposition and/or suppress (armed) rebellion, something which results in political stability and a lower risk of internal violence. The theory is therefore focused not so much

6 But the three Gulf wars (Iraq vs. Iran 1980-1988, Iraq vs. Kuwait, US and its allies 1990-1991, USA vs. Iraq 2003) allow for the assumption that resource wealth also raises the risk of interstate wars, which in turn is relevant for the region under analysis here. The resource curse thesis could therefore be useful when these kinds of conflicts are analyzed. 
on violence as on the phenomena of state stability and authoritarianism in oil-exporting countries, which, however, sometimes include violent repression.

The criterion of oil-induced government spending seems applicable to both the shah's regime and the Islamic Republic (Beck 2007: 52f.). However, to describe and classify both as "rentier states" does not necessarily substantiate the causal claims of the theory, that is, that rentierism must invariably be linked to authoritarianism and an undiversified economy based on large-scale distribution, both of which should favor regime stability when oil prices are high. While convenient for the analysis for Middle Eastern states, the rentier theory has difficulty when confronted with moments of political change which seem to have no relation to changes in resource revenues. The question of the Islamic Revolution, which marked the transition from a monarchy to a radically different regime in 1979, might not fall within the main paradigms of the rentier state theory, but the puzzle it raises should nevertheless be taken seriously. This puzzle could be resolved by using the assumptions of the resource curse approach described above. As already stated, this discussion assumes that there are additional factors - only partly or not at all linked to the resource endowments - which influence whether or not there is an outbreak of violence. These contextual conditions will be elaborated on in the following section.

\subsection{Integrating the Context: An Extended Causal Model}

To understand the variety of mechanisms leading to violence or securing its absence, it is useful to look more closely at the specific historic, cultural, economic, demographic, and other contextual conditions and their changes over time in a given country, together with that country's geopolitical position. Of course, it is impossible to make an exhaustive analysis given the innumerable factors influencing the course of political history and the outbreak of violence in a single country. Different sets of variables can, however, be identified and their impact hypothesized.

The context approach is not incompatible with the theories described above; it aims mainly to bridge the gaps they leave (also between them) and to address specific conditions for violence that have been neglected so far. It can help to differentiate at which level the resources function as a factor influencing conflict. It could, however, also reveal that other contextual conditions weigh much more heavily than the resources do. For a clearer picture of the causes of violence, it is useful to distinguish between four different dimensions of variables. First, the resource-specific contextual conditions which are directly linked to the oil resources in the country and to the international oil market, etc. Second, the non-resource-specific contextual conditions that are a very broad range of variables that can be indirectly linked to the oil wealth or are independent of it. Both sets of variables can be further differentiated into internal (that is, domestic) and external (that is, international) variables, resulting in a matrix with four fields (see Table 1). 
Table 1: Matrix of Factors in the Context-dependent Relationship between Resource Wealth and Violence

\begin{tabular}{|c|c|c|}
\hline & Resource-specific & Non-resource-specific \\
\hline Domestic & $\begin{array}{ll}\text { - } & \text { Type(s) of resource(s) } \\
\text { - } & \text { Degree of abundance } \\
\text { - } & \text { Degree of dependence } \\
\text { - } & \text { Tocation of resources within the country } \\
\text { - } & \text { Resy") } \\
\text { - } & \text { distribution modes of extraction ("lootabil- } \\
\text { - Direct economic effects of oil }\end{array}$ & $\begin{array}{ll}\text { - } & \text { Socioeconomic factors } \\
\text { - } & \text { Demographics (e.g. "youth bulge") } \\
\text { - } & \text { Geographic factors } \\
\text { - } & \text { Intergroup relations (social, ethnic, religious) } \\
\text { - } & \text { Substate actors (parties, civil society) } \\
\text { - } & \text { Efficiency and legitimacy of institutions (in- } \\
\text { - } & \text { cluding security sector) } \\
\text { - } & \text { Political ideas and ideologies) }\end{array}$ \\
\hline $\begin{array}{c}\text { Inter- } \\
\text { national }\end{array}$ & 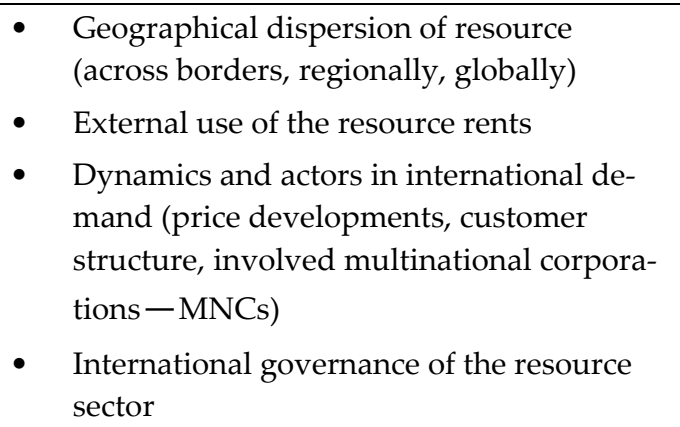 & $\begin{array}{l}\text { - } \begin{array}{l}\text { Relations with neighboring countries, re- } \\
\text { gional and global powers }\end{array} \\
\text { - } \begin{array}{l}\text { Interdependence of the country (economic/ } \\
\text { political) }\end{array} \\
\text { - General conflict potential in the region (spill- } \\
\text { over effects) } \\
\text { - Regional and international governance/ } \\
\text { system }\end{array}$ \\
\hline
\end{tabular}

Source: Author's own compilation based on Basedau 2005.

These contextual conditions will be elaborated on when they are applied in the empirical part of the paper. They have to be understood as dynamic as they evolve with time; they are also not independent from each other, as there may be numerous connections between them, as illustrated in Figure 1. 
Figure 1: $\quad$ Interplay of Contextual Conditions

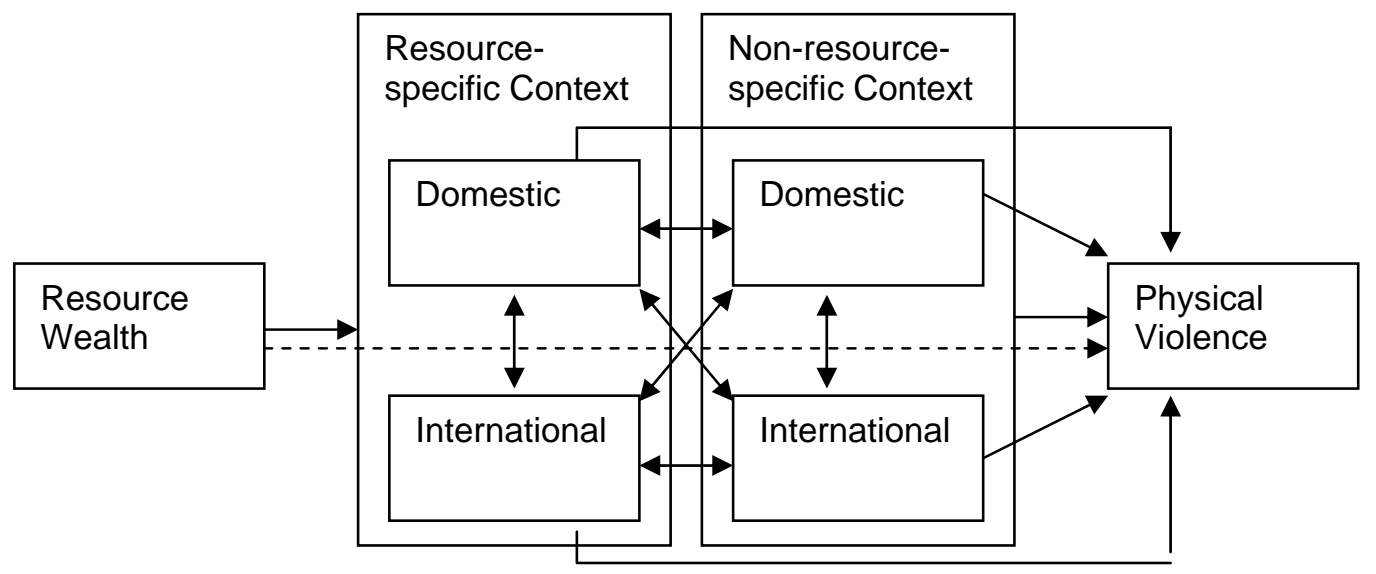

Source: Author's own compilation based on Basedau 2005.

The aim of this study is to detect the importance of contextual variables and their interplay in the case under examination, which calls into question assumptions of a universal link between resource wealth and violence. In doing this, the study strives to contribute to the critique of mainstream theories and theoretical approaches.

The application of this complex model to a case study and to a small-N comparative analysis allows for a deeper investigation of the evolution of a country's context than is possible in large-scale comparative studies. As contextual conditions evolve with the changes resulting from the increased importance of oil in an economy, it is also fruitful to consider the situation before the resource extraction started (Smith 2004: 243; Basedau 2005). It may turn out that the "resource curse" vanishes when the context preceding resource extraction is taken into account (Basedau 2005: 27, Brunnschweiler/Bulte 2006). It may also turn out that only an analytical model that takes the complexity of the context into account makes possible more appropriate conclusions on the question of how to tackle violence.

\section{Context and Causality in the Case of the Islamic Revolution}

The following discussion will examine the Islamic Revolution, with a special focus on the violence connected to it. ${ }^{7}$ The aim is to determine the nature of the interplay between different sets of contextual conditions which favored the revolution's occurrence, and whether the influence of resource-specific conditions outweighed that of non-resource-specific condi-

7 It is acknowledged, however, that the revolution itself was not as violent as other cases considered in the comparative study or events in other periods of Iranian history, and that regime changes-be they through revolution or military coup-do not need to be violent in terms of the number of deaths. However, as will be demonstrated, violence and the reaction to violence indeed played a role. 
tions. After a short summary of key details, the various contextual conditions will be presented in condensed form. A discussion of the impact of the resource-specific contextual conditions over the non-resource-specific contextual conditions will follow.

\subsection{The Overthrow of an Oil-backed Regime with a Pinch of Violence}

The Islamic Revolution does not fit within the rentier state theory, but in a certain way, the shah's regime and the Islamic Republic do (Najmabadi 1987, Beck 2007: 52ff.). A closer look at the resource-specific context reveals the extent to which the oil rents played a role in the deterioration of the relationship between the state and its society in the years before the revolution, and also how they were used as an instrument to weaken the regime. However, a broader look at the general context, not specifically linked to oil, shows that there were deeper forces at work which were not merely related to the oil income.

\section{The Revolution's Context}

The onset of the revolution began in late 1978 with increasingly violent strikes and demonstrations. Within a few months (on February 11, 1979), the monarchical system was overthrown and replaced by a new form of regime, conceived of by its makers as a mixture of theocracy and republic. A coalition of opponent groups-socialists, communists, and religious leaders-had combined forces and organized the revolutionary movement. Masses of people had participated in spontaneous marches to express their dissatisfaction with the shah's regime. The masses did not have weapons, but the military had shot at them. Through this violence, they unintentionally martyred some of the protesters, thus contributing to ever-growing protests. Changes in both the resource-specific and the non-resource-specific context together contributed to the force and success of the mass movement.

\section{a) Domestic Resource-specific Context}

Iran's oil resources had a growing importance for its economy throughout the last century and especially as of the 1970s, with both beneficial and detrimental effects.

Degree of Abundance. Iran's resource wealth had shaped the economy of the country, and it offered important financial backing for the shah's regime. The amount that the sector generated for the Iranian regime and for foreign companies is difficult to measure. However, the level of wealth was especially impressive when external benchmarks were taken into account. When it came to internal wealth, the situation was less definite. Because of the size of its population, Iran was not so wealthy in comparison to other states: in 1978 its income per capita from the oil sector was approximately US\$652, while in Saudi Arabia it was US\$4,504 and in Kuwait, US\$8,858 (EIA 2008). ${ }^{8}$ Oil income rose considerably during Mohammad Reza Pah-

8 The difference today is even more visible, with per capita income in 2007 totalling US $\$ 873$ for Iran, US $\$ 7,031$ for Saudi Arabia, and US\$21,858 for Kuwait (EIA 2008). If the stocks are put into relation with the growing 
lavi's reign, as new discoveries were made, new wells were drilled, and prices soared. Production rose equally, to heights never attained again. Furthermore, after 1953 a larger share of oil profits was given to the Iranian state by foreign oil companies operating in the country, the reasons for this will be elaborated on later on.

Degree of Dependence. It was not so much the wealth in itself, but rather the dependence on the resource sector that made the regime vulnerable. The state relied heavily on income from the hydrocarbon sector, which accounted for approximately 80 percent of its budget (Fürtig 1987: 130). In the late 1970s, the state obtained four times more revenue from the oil sector than from tax extraction (Razavi/Vakil 1984: 91). This dependence on the part of the central state was most visible during the revolution, when the oil workers played their part in weakening the regime (Fürtig 1987: 130). In 1977/78 there were many mass strikes all over Iran, and it was the workers and employees in the oil industry who particularly got the regime into trouble when they closed the pipelines and stopped all oil production and exports (Ehsani 2005). Seen from this angle, the opportunity aspect of the resource becomes more traceable: oil was a highly useful medium for those opposed to the state to cut its income. The oil workers' strike deprived the shah of his main income and thus delivered the final blow to his regime.

Resource-sector Management. The rentier state theory predicts authoritarianism on the part of governments that are-due to oil income-financially independent from their societies. In order to keep the level of opposition low and the power in the hands of the rulers, there will very probably be a certain level of violence. However, co-optation can also result from and depend on oil revenues: "The increase in good governmental jobs, salaries, and prerequisites as oil income grew made [the co-optation of opponents with jobs] an effective strategy for a time, but did not bring about real loyalty to the shah" (Keddie 2006: 134). The Islamic Revolution took place at a time when oil prices were still quite high, and the shah was indeed using the oil income in a way compatible with the assumptions of the rentier state theory: he spent the money on his (over-)zealous modernization efforts. He further increased his arsenal of weapons, which he used for external deterrence and power display-and for internal repression. The arms purchases of the Iranian government increased in a very similar manner to the oil revenues..$^{9}$ Iran's defense budget was increased from US $\$ 1.4$ billion in 1972 to

population size, the in situ wealth of Iran is also less impressive: it was approximately 1,490 barrels per capita in 1980 and 1,990 in $2005^{8}$ (calculated from BP and WDI data). In Saudi Arabia, in comparison, there were 17,495 barrels per capita in 1980 and 11,428 in 2005 with 11,428. The latter's numbers are a little lower now, but still almost eight times higher than those of Iran.

9 The shah expanded the armed forces (army, gendarmerie, air force, elite commandos, Imperial Guard) from 120,000 men in 1953 to over 200,000 in 1963, and even to 410,000 in 1977. The annual military budget was increased from US\$80 million in 1953 to nearly US\$183 million in 1963 (at 1960 prices and exchange rates) and from US\$293 million in 1963 to US\$1.8 billion in 1977 (at 1973 prices and exchange rates) (Abrahamian 1982: $420,435)$. This, however, was not always covered by oil revenues, which were lower than expected in the 1950s and late 1970s, but rather - and this quite heavily - financed by loans (ibid. 422). 
US\$9.4 billion in 1977 (Pollack 2004: 108). By 1977, the shah had the largest navy in the Persian Gulf, the most up-to-date air force in the Middle East, and the fifth-largest military force in the world (Abrahamian 1982: 436).

It must be noted that a slight drop in oil prices in 1977, after their first climax in 1973, preceded the revolution. It is not likely that this was the single reason for the massive public rebellion and the overthrowing of the regime (Beck 2007: 52). However, this slowdown in oil prices-even if not so important in numerical terms, as the nominal barrel prices of 1977 and 1978 were identical and only the real price was dropping (EIA 2008) - was sudden and unanticipated. The shah's leading economists later explained that the government had not even considered the possibility of a drop in oil prices (Razavi/Vakil 1984: 90); it had started projects that required rapidly increasing oil revenues for their financing (Pollack 2004: 120) and it relied heavily on loans contracted against anticipated rents (Abrahamian 1982: 422). With the fall in the oil price, the government suddenly stopped or slowed down many ambitious development projects and wages were cut. In summer 1978 unemployment jumped from almost zero to 400,000 persons (ibid.: 511). The government's policy towards labor became tougher, and this incited the protest of the working class (ibid.). Given these outcomes of oil price instability, the rentier state theory becomes even more applicable in understanding the instability of the late shah's regime.

Economic Distortions. The indirect impacts of resource rents that emerged during the boom period were also negative, causing, among other things, economic distortions often summarized as "Dutch Disease" effects. ${ }^{10}$ The effects of high oil prices on inflation and the exchange rate probably were (and still are) at work in Iran, but in a modified way. Asghari (1998: 35) therefore speaks of "Iranian Disease." Increased spending by the central state led to higher import rates (also of food) and higher wages in the industrial sector. The stagnation of the agrarian sector and the expansion of the industrial sector were the consequences (Asghari 1998: 35). This phenomenon partly explains the problems of diversifying the economy and of the tendency to increase imports; it can contribute to high inflation and an increase in unemployment. These economic distortions very probably contributed to the population's growing dissatisfaction:

There were problems arising from the accelerated development spending after the 1974 oil price rises: widespread corruption, economic and infrastructural bottlenecks of various sorts, and by 1977, rampant inflation and unemployment in some sectors. But

10 The basic argument is that high windfalls from natural resources - be it through a sudden price increase or through the discovery of new resources-function as a shock and can lead a country's economy to import more and to export fewer goods, excluding the resources in question, which in turn harms the manufacturing sector. An appreciation of the real exchange rate has been diagnosed as the mechanism responsible (Williamson 2008: 12). This effect was observed in the Netherlands in the 1970s after the discovery of and during the exploitation of a major gas field. 
$[\ldots]$ with huge oil revenues at hand, and a strong army, there was no compelling reason for the Pahlavi state to collapse so completely and so rapidly.

(Najmabadi 1987: 211)

Insiders believe, however, that the measures the government applied to restore fiscal order only intensified the crisis (Razavi/Vakil 1984: 95). After several years of constant and exhilarating growth, many Iranians had found work and had begun to earn at least a slightly higher income than before, but this changed suddenly with the oil-price decline in 1977 . The deflationary program then applied by the government as a result of the oil-price decrease brought a sudden growth in unemployment, especially among the unskilled and semiskilled, and this, coming after rising expectations, helped create a classic preRevolutionary situation. The combination of inflation, shortages and large and evident income distribution inequities probably contributed more to a growing discontent than did the standard factor cited in the West of too rapid modernization.

(Keddie 1981: 177 quoted in Razavi/Vakil 1984: 95)

Eighty percent of the private property in Iran was in the hands of only 1 percent of the population (Fürtig 1987: 81), while the clear majority was living in poverty. These numbers illustrate well the starkness of the inequality; even so, the shah did not reduce the "huge sacrosanct military budget" (Keddie 2006: 217).

In sum, the impact of factors related to the oil resources and the country's growing dependency on them should not be underestimated. In addition to the mismanagement of the resource sector and the internal pressures resulting from it, external factors related to oil played a role as well.

\section{b) International Resource-specific Context}

As will be shown further on in the analysis, external interference had significant repercussions for the Iranian population and fuelled its anger towards the shah's regime. Therefore, the relevant resource-specific reasons for this interference need to be examined. The dynamics of international demand are considered particularly relevant here, as are the strategies of external actors.

Interests and Strategies of External Actors. Quite enlightening is a consideration of external interests in the Middle East in general. These interests can be plausibly linked to oil (but not oil alone). The British were the first to explore for oil in the region and obtained a long-term concession, which they exploited for more than 40 years (1909-1951) through the AngloPersian Oil Company (APOC), ${ }^{11}$ until the company was thrown out of the country by the Ira-

11 In 1935 the company was renamed the Anglo-Iranian Oil Company (AIOC) and later, in 1954, it became the British Petroleum Company (BP). For Pollack, the AIOC “was a rapacious and careless company [...] determined to maximize immediate profits" for which it "manipulated its books to underpay the Iranian government to the tune of billions of dollars" (2004: 52). 
nian nationalization movement. While Iran never had the status of a colony, the history of imperialism in matters of oil is very much the same as that of colonialism. ${ }^{12}$ Iranian oil played an important role in sustaining Britain's industrial power and military, and it contributed to the Allies' victory in World War II (Kleveman 2004: 18). During the entire period of Britain's monopolistic activity in Iran, the host country received only a minor share of the profits. The "rent" factor of oil only became relevant for Iran years later. While the British company indeed exploited the country's resources and workers, some observers consider the reaction towards it to have been exaggerated and highly emotional. ${ }^{13}$ The company did not give any concession to the Iranians, who were demanding a 50 percent share of the profits similar to the Saudi-Aramco deal between Saudi Arabia and US oil companies in 1950 (Yergin 2003: 449). This immediately had an impact on events in Iran. In 1951, the full-fledged nationalization of Iranian oil resources was obtained by Prime Minister Mohammad Mossadegh.

This move-and particularly its consequences - was a turning point for Iran. The government got into immediate trouble with the British, who viewed this policy an affront to what they considered as their right. ${ }^{14}$ As they could not act alone, they asked the US for help, and in the end, a CIA-led putsch changed the course of events. ${ }^{15}$ Mossadegh was chased from office, and the shah came back from his brief exile shortly afterwards. After the coup, the British AIOC (soon renamed British Petroleum-BP) was limited to a share of 40 percent of the Iranian oil sector; a further 20 percent was controlled by Royal Dutch Shell and Companie Françasie de Pétrole (now TOTAL S.A.). Finally, as a reward for this successful coup, the United States took over the dominant place of the British in the Iranian oil sector: from then on American oil companies controlled a 40 percent share of the Iranian oil sector.

This consortium officially gave Iran 50 percent of its profits, but as it did not "open its books to Iranian auditors or [...] allow Iranians onto its board of directors" (Kinzer 2008: 195f), it is questionable if the amount really was that high. This lack of transparency and the previous

12 Author's interview in Tehran, May 29, 2008.

13 Author's interview in Tehran, April 29, 2008.

14 Britain had tried to get the Iranians rescind their action and, after an initial, violent confrontation, they took the case to the World Court. During the three years of their dispute, Britain threatened to sue probable buyers of Iranian oil. They were successful with this strategy, as Iran sold only an insignificant amount during that time (Pelletiere 1992: 3).

15 At first, the British were considering a putsch or a military intervention and were already proceeding in their military build-up (Pollack 2004: 56), but as all British diplomats were soon expelled from the country, they could not do anything from within. The USA came to their aid and wanted to avoid a military operation for fear of involvement by the Soviet Union. The change in office in the US from President Truman, who opposed the British plan, to Dwight Eisenhower in 1953 was a central change in the international context. The US immediately opted for a putsch. Together with the British, they chose General Zahedi as the leader of their coup (Kinzer 2008) and the CIA organized (and paid) a mob to incite demonstrations against Mossadegh. They also collaborated in a "last-minute-deal" (ibid.: 178) with Muslim religious leaders to enlarge the mob: Ayatollah Abulqasim Kashani, a powerful fundamentalist cleric who first supported Mossadegh but then turned against him, received US\$10,000 for this purpose from Kermit Roosevelt the day before the coup (ibid.: 178). 
external interference linked to oil in Iran contributed significantly to the population's grievances towards outside forces and their own regime, seen as collaborating with these forces. It was only with the revolution that oil production was 100 percent nationalized and the Western companies were thrown out of the country. The National Iranian Oil Company (NIOC), established in 1948 and affiliated with the Petroleum Ministry, has since been fully responsible for oil production.

But it was not only Western powers which had an eye on Iranian resources-even if they dominated in the oil-rich southern provinces and in terms of their influence on the central state. The Soviet Union also repeatedly tried to exploit the momentary weaknesses of the regime and extend its influence, mainly in the northern parts of the country. At the same time as British forces were invading the southern parts of Iran in 1941, Soviet troops occupied the northern parts of the country-and stayed. Only in 1946, in exchange for the Iranian government's promise that the USSR would get an oil concession in the north of Iran, were the troops withdrawn (Bamberg 1994). Thus, also from this side, oil interests become obvious. It has to be noted, however, that the aim of territorial domination goes beyond mere resource calculations.

Dynamics in International Demand. The international oil market underwent a fundamental change at the beginning of the 1970s, with the producing countries, many of them members of the Organization of Petroleum Exporting Countries (OPEC), gaining in income and influence, and pushing prices up. Given the economic importance of oil, for both buyer and seller countries, there were dependencies which made the delivery of oil a political problem. Iranian oil was important for the rising transport- and industry-related needs of the Western world. The British and then the US also used it for their military activities. For European and American industry, especially the armaments and automobile industries, it was very profitable to do business with Iran. During the first oil crisis in 1973, the Arab OPEC member countries wanted to put pressure on the states allied with Israel and at the same time welcomed an increase in the low price due to the reduction in supply. Iran did not take part in either the war effort against Israel or this production curb, but it was one of the countries which most profited from it, and it even increased production by 600,000 barrels per day (Pollack 2004: 107). With the oil workers' strike, Iranian oil exports were first reduced drastically and then stopped completely at the end of 1978. This proved to be a pivotal event on the world oil market (Yergin 2003: 681) and, together with the success of the revolution, it initiated a worldwide panic.

Geopolitics Related to Oil. After Britain's retreat as the major defender of its own and Western interests in the Persian Gulf region in 1971, the United States took the lead. However, it did not take on all the responsibilities of its predecessor; for internal reasons such as the Vietnam War and the economic recession, this was not an option. "Nonetheless, President Richard Nixon recognized that Western interests in the Gulf must be protected, and-in what appeared to many at the time to be an ingenious solution-he made the shah of Iran, 
Mohammad Reza Pahlavi, the regional protector for the West" (Pelletiere 1992: 7). The second country playing this role of regional watchdog was Saudi Arabia, which was integrated in the so-called "two-pillar" policy of the US. From today's vantage point, this "Nixon Doctrine" was unworkable in the long run. The shah was overstrained by this responsibility, and he aroused the mistrust of the Ba'thists in neighboring Iraq, thereby laying the ground for the Iran-Iraq War (ibid.). Further, his interests did not always match the interests of the West, for instance, in the case of the oil price. Prior to the oil crisis, the OPEC countries were already pressing to raise their share of the profits. The shah was the first to advocate successfully for a higher level of profit-sharing, obtaining 55 percent of the profits of the consortium companies operating in Iran in 1970 (Yergin 2003: 580). This led to intense bargaining in other oilproducing countries and within the OPEC cartel.

The price drop of 1977 needs to be looked at from an external standpoint as well, as it reveals the ambivalence of the US-Iran relationship. A planned oil-price increase that the OPEC members wanted to approve at a meeting in Doha in December 1976-the shah being one of the main supporters-was torpedoed by Saudi Arabia (Cooper 2008: 567). One reason for Saudi Arabia's opposition was its fear of an overambitious Iran, which already played the role of the "policeman in the Gulf" and very likely aspired to become a hegemon in the region. This fear was also linked to suspicions of a conspiracy between parts of the US administration and Iran. These fears were not unfounded, as there had been a "Kissinger-Shah plan for Iran to occupy Saudi Arabia and seize its oil assets in the event of political unrest in the Kingdom" (ibid.: 579). Other parts of the US administration, however, especially the influential treasury secretary, William Simon, had close connections to Saudi Arabia's minister of oil and mineral resources, Shaykh Ahmed Zaki Yamani (ibid.). In this sense, the famous "two pillars" in the Middle East were, following the shift in the US -presidency in 1974, supported by two different parts of the US administration. While Nixon and Kissinger had had a rather pro-Iranian stance, the new US president, Gerald Ford (1974-1977), was increasingly losing interest in supporting the shah. He particularly blocked any request by the shah to increase oil prices, an issue in which the two countries had fundamentally different interests. The Ford administration, "which had gone to great lengths to calculate the damage an increase in the price of oil would inflict on the American economy, apparently never attempted to measure the possible impact on the shah and Iran's economy if the price rise did not go ahead" (ibid.: 589). The US supported Saudi Arabia instead, which raised production in 1977 by 657,000 barrels per day, together with the United Arab Emirates, which augmented its production by 61,000 barrels. All the other OPEC members decreased production, but the cumulative decrease was only 540,000 barrels (BP data set 2007) and the result was a total surplus of 178,000 barrels. The envisaged price increase failed, and this contributed to the price drop of 1977 and its fatal consequences for the Iranian economy and the shah's regime. In the eyes of the Iranian population, the shah's failure to obtain the promised oil-price increase also did no good to his reputation. 
As demonstrated above, Iran's oil and oil income were relevant to political developments, especially when external contextual variables are taken into account. The shift in power in the US was relevant to the weakening of the shah, and the revolution then impacted back on the internal policy of other states. Before the revolution, oil had "lashed the United States more tightly to Iran than had ever been the case before. [...] Suddenly, what happened in Iran was critical to the American economy, and to the entire global economy" (Pollack 2004: 101). Therefore, the Iranian Revolution and the strikes that preceded it had a strong impact on the global oil market, triggering the second oil-price shock soon thereafter, with all its repercussions for the domestic economies of oil-importing states.

The discussion up to this point has confirmed the importance of resource-specific contextual conditions, or at least a selection of them, in the incidence of violence in Iran. They provided both the motive and the opportunity for different actors to push their own interests, and this was sometimes (but on a limited scale when compared to other conflicts) linked to violence. However, the oil sector had mainly indirect impacts. Its influence needs to be contrasted with contextual conditions either not linked or indirectly linked to the resource sector, as will be done below.

\section{c) Domestic Non-resource-specific Context}

In addition to the above, and indeed relevant, influences of the resource sector, there were many dynamics in the non-resource-specific context that were at the core of the revolution, as will be demonstrated in the following discussion.

Socioeconomic Development. Among the major reasons often given for the high degree of indignation towards the shah's regime are its forced and awkward modernization efforts and its disdain of tradition. Shah Mohammad Reza Pahlavi followed with enthusiasm his project of "The Great Civilization," a sort of big push strategy to industrialize Iran, thereby accelerating its economic development and decreasing its dependency on oil revenues, as the depletion of the oil sources was pending (Razavi/Vakil 1984: 66). The plan was to realize the Great Civilization within a record time of 20 years-essentially by using the alluring oil riches to buy everything from Europe and the United States without really considering the question of whether there was adequate demand or whether the population had the skills to work immediately with the imported industrial assets (Kapuscinski 2006: 59). For this reason, thousands of foreign experts and workers were hired to work in the huge factories. The shah's father, Reza Shah, had already started the modernization process by building railroads, factories and universities, in a style comparable to Ataturk. Both shahs' focus on developmentalism produced a culture of technocracy in government. "The positive side of this trend was that greater emphasis was placed on bureaucratic excellence, and investment in various state institutions was increased" (Gheissari/Nasr 2006: 56). The negative side was that "[t]he focus on development in the absence of competitive politics made the bureaucratic elite immune to demands from below" (ibid.). This distance between people and decision-makers was thus 
not only due to the oil boom and the rulers' financial independence, but was also linked to a general ideology represented by them.

While the government had increasingly more money to spend, the actual value of this money dropped considerably. Inflation was low in 1970 at only 1.6 percent, but it rose to 4.2 percent in 1971 and even reached 27.1 percent in 1977-according to Iran's own figures. The IMF even assessed the inflation rate as being approximately 50 percent annually in the years 1975 to 1977 (Pollack 2004: 111). This, of course, threatened the status and the savings of the middle class and added to the misery of the lower classes (ibid.). Generally speaking, the middle class was most likely the source of organized opposition to the regime, being better educated and more economically flexible than the masses of the poor, who were preoccupied by their daily needs, but who could be activated for protest later on.

Demographic Changes. Population size and demographic dynamics can also play a role in the stability of a regime and impact the level of domestic violence. The Iranian population had been growing fast since the 1960s - by approximately 3 percent annually. The population counted 22 million in 1960 and grew to 38 million in 1979, the year of the revolution. The resulting "youth bulge" can be considered to have been a stress factor which, combined with other unfavorable conditions, increased the likeliness of upheaval and conflict (Urdal 2004). Employment had increased by 25 percent in the years from 1962 to 1971, but the economically active population had grown by 75 percent over the same period (Pollack 2004: 112). Millions of young people were entering the labor market, and this contributed to a serious job shortage in the first years of the 1970s. The urbanization rate was particularly impressive (Figure 2).

\section{Figure 2: $\quad$ Urban Population as Share of Total Population in Iran}

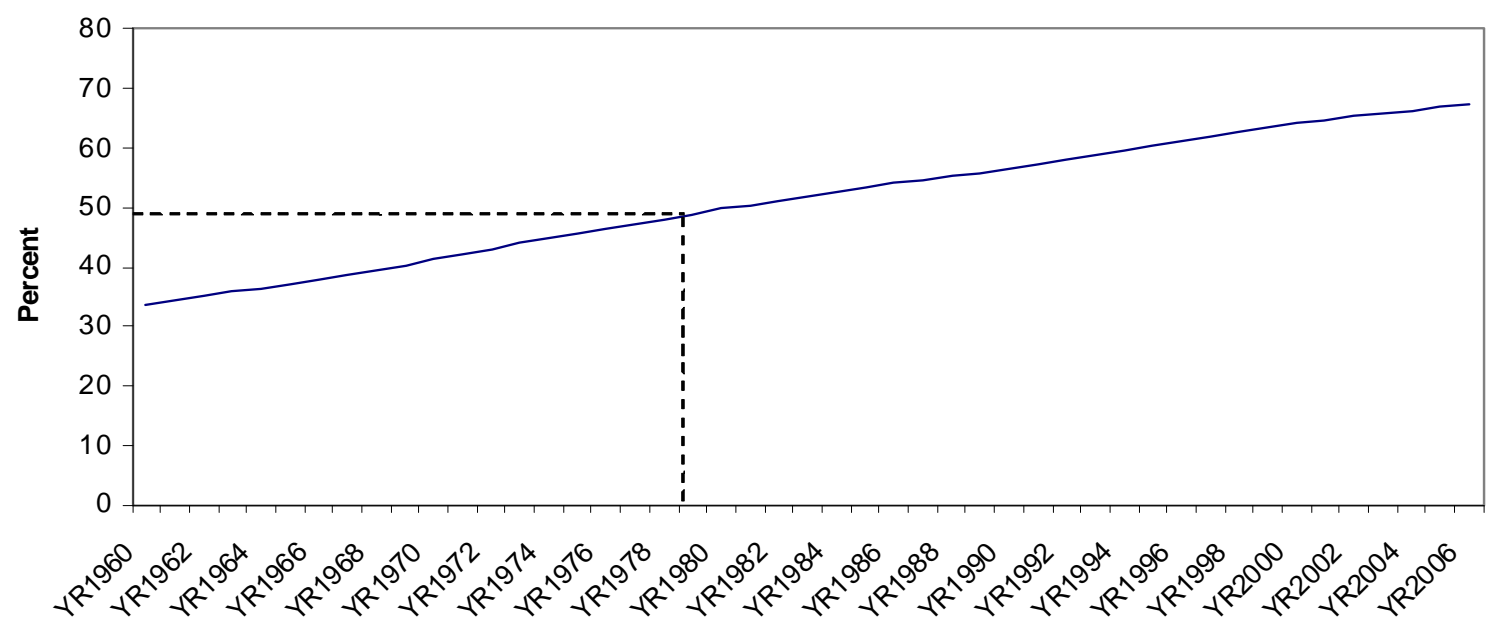

Source: WDI Development Indicators. 
It is striking that a little more than "[ $\mathrm{t}]$ wo decades ago the urban population of Iran, for the first time in history, exceeded $50 \%$ of the total population. This symbolic passage to a predominantly urban society occurred at the same time as the Iranian Revolution" (Ehsani 2005: 5). Huntington (1971) has theorized that urbanization produces instability when it happens too quickly. Rapid and high urbanization rates also prove in international comparison to be robustly linked with a greater risk of regime failure (Smith 2004: 238). Iran's policies did not cope adequately with this rapid urbanization; for instance, the government made little effort to subsidize low-cost housing. Housing rents soared, shantytowns expanded, and more and more families lived in very small spaces - all despite the huge national income (Pollack 2004: 111). The effects of "Iranian Disease," mentioned above, among the other factors weakening the agricultural sector, probably accelerated this urbanization. Due to population growth, agricultural production could not keep pace with demand, and in 1977 the government had to import 25 percent of Iran's annual food needs, the costs for which amounted to 10 to 20 percent of Iran's annual oil revenues (ibid.). This was partly a consequence of political miscalculations and a system very favorable to imports.

Quality and Efficiency of Institutions. The Pahlavi regime was a highly centralized and hierarchical monarchical regime with the shah at its top and center, exercising complete decisionmaking power in political and military matters (Pelletiere 1992: 12ff.). This arrangement maximized his power but made the whole system extremely dependent on the quality of his decisions - and extremely inflexible. There were other constitutionally required institutions, however, such as the parliament (Majles) and the prime minister, which could compete in certain domains with the shah's power. The first period (1941-1953) of Mohammad Reza's reign was marked by his weakness, which "encouraged greater political activism among liberal nationalists and democrats. The opening of the political system, greater freedoms of the press and association, a more prominent parliament, and a growing private sector and bazaar all strengthened the impetus for political debates, party politics and competition for power" (Gheissari/Nasr 2006: 47). But after the coup against Mossadegh and the reestablishment of the monarchy, the shah was better able to consolidate his regime (Pollack 2004: 52), not least because of its higher share of oil revenues and because the period of democratic opening up was over. Aside from the shah himself, however, there was no strong institution which could have carried on his reforms after a shift of power, such as, for instance, Ataturk's Republican People's Party in Turkey. In 1975, the shah tried to remedy this and founded the Rastakhiz (Resurgence) Party, which from then on held a monopoly on political activity in Iran. He even decreed that all Iranian citizens and the few remaining political parties must become part of it (ibid.: 116), something that did not do much to augment its legitimacy in the eyes of the public.

Since the 1960s, the shah had developed a sophisticated security system. The army, as demonstrated above, was well equipped, and the police force expanded. However, repression mainly took place through the secret service of this time: the SAVAK (Sazeman-e Ettela'at va 
Amniat-e Keshvar, Engl.: National Intelligence and Security Organization), founded in 1957 and dissolved with the revolution. During the 1960s and 1970s, it was able to suppress numerous threats against the shah with brutal efficiency (Pelletiere 1992: 15). In the end it had approximately 5,300 full-time agents, plus a large but unknown number of part-time informers (Abrahamian 1982: 436). "One part of SAVAK was involved in the jailings, beatings, and tortures that became notorious in the years before the revolution, but there were also suave, educated operatives in coats and ties who persuaded people of the dangers of speaking or acting out of turn" (Keddie 2006: 134). Given the threat of jail, torture, or even death, it is not surprising that political activity was limited and very careful for a long time (ibid.). SAVAK ultimately lost its fear-inducing effect during the revolution. As many of Khomeini's followers were ready for martyrdom, the security apparatus and the army became virtually helpless (Pelletiere 1992: 15). As the wish of many Iranians to participate in politics grew stronger and stronger, oppression apparently did not succeed in dismantling it entirely.

Intergroup Relations. The policies undertaken by the shahs need to be seen against the background of the different groups within the Iranian society, and their values, norms, and societal power. The modernization efforts of both shahs were also an effort to expand their power and attack entrenched and hostile centers of power inside the country, such as the wealthy landlords and the clergy (ibid.: 11). The land reform effectuated by the shah in the 1960s unintentionally contributed to the migration flows which brought many peasants to urban areas, which led to a socially explosive situation. Millions of new urban dwellers who had grown up in traditional settings in small villages were overwhelmed by what they saw in the towns, especially in Tehran. ${ }^{16}$ On the one hand, they saw luxury they had not even dreamed of before; on the other hand, the shah's regime tried to make them leave their traditions behind, condemned what they cherished, and openly tried to "Westernize" Iranian society. Often, drastic social change brings a loss of identity and cultural alienation with it, and the strong reaction of people defending traditional and religious norms brought many Iranians into an identity conflict (Naficy 1993: 19). This is important to note in order to understand the ferocity of their later resistance: the power structure was becoming more and more antagonistic to the culturally ingrained worldview of the majority of Iranians.

A society that is also deeply split into wealthy and poor people has a higher potential for violence-which can, however, remain latent. If those divergences start to shift, for example, the disparity is reduced or augmented, the probability of violence increases (Hippler 2006: 67). In particular, the divergence between the expectations and hopes of large parts of the population on the one hand and the social realities on the other can trigger violence (ibid.: 72). In 1972/73, approximately 44 percent of the population was undernourished (Pollack 2004: 113) and a high number lived in shantytowns, while other parts of the society were getting richer. The animosity of many middle- and lower-class Iranians towards the deepening economic

16 Author's interview in Tehran, May 14, 2008. 
gap was reinforced by the feeling that the super-rich had become so illegally. Corruption, which had been "tolerated as an accepted part of social and economic life, now grew to such proportions that even the tolerant considered it obscene" (Ansari, quoted by Pollack 2004: 113). The oil boom and bust had a clear effect on this gap.

Behavioral Patterns of the Elite. For Luciani, the case of Iran does not provide an argument for the weakness of the rentier state theory, as "the Shah was more preoccupied with promoting aggressive industrialization, even at the cost of exacerbating class conflict, than with buying political support" (Luciani 1987: 76). He also invested frenetically in the newest available weapons, which caused fundamental misunderstandings with his critics within Iran and with his neighbors (Pelletiere 1992: 13). The fact that it was possible for a single leader to miss effectively "buying off" the opposition leaders in the society, which would have been a prerequisite for the regime's survival, and to overestimate his own power in activities against the clergy shows that the effects of resource wealth are also very much subject to the mistakes and miscalculations of actors and therefore not necessarily deterministic.

The economic elite was rather depoliticized and primarily concentrated on the accumulation of wealth. An important section of the commercial bourgeoisie, the traders or bazaaris, supported the revolution, but "this class had been bypassed politically under the Shah and had become less significant in relative economic terms as a result of the economic and social developments of the preceding two decades; it no longer constituted a part of the political elite of the country" (Najmabadi 1987: 212). The bazaaris suffered from almost every aspect of the shah's economic policies, "from its regressive taxes to its antiprofiteering campaigns to its lending policies to its price controls to its emphasis on heavy industry and imports" (Pollack 2004: 114). They feared the growing competition with foreign companies and the emergence of a new bourgeoisie within Iran (Fürtig 1987: 62). Perhaps their wish to regain the position they had lost due to the growing importance of oil in the economy made them inclined to back Khomeini's call for regime change and to promote the revolutionary movement through the complex network of informal social ties they had with the Shi'a clerics (Naficy 1993: 17). Political Ideas and Ideologies. Iran's development of political movements was fundamentally entrenched within the context of the suppression of political ideas described above. During the reigns of both Pahlavi shahs, all democratic associations, independent labor organizations, and oppositional political parties disappeared (Dadsetan 2003: 342). The liberal and moderate groups and the socialist Tudeh Party were also suppressed. When authoritarian states destroy all forms of free expression, annihilate all opponent organizations, and leave no space for civil society, they deprive the population of legal measures for the expression of their dissatisfaction. In doing this, such states encourage revolts and the use of violence as the sole possible reactions to the violence and repression exercised by the dictators (ibid.). Several violent groups, such as the Fedayin-e Khalq and the Mojahedeen-e-Khalq (MKO), were using violence in their struggles against the regime. They laid bombs, committed political assassinations, and were very militant. The MKO was also responsible for the assassina- 
tion of several US military personnel and civilians in Tehran in the 1970s, and it supported the violent takeover of the US Embassy in 1979 (US Department of State 2007). During the revolution, the group was an important supporter of Khomeini, though this liaison did not last for a long time.

Because of the large-scale repression of different opposition forces, paired with the widening gap between the elite and the majority of the population, it became increasingly likely that "eventual effective opposition would come from those who could appeal to the traditional disaffected masses more than from Westernized liberals or leftists" (Keddie 2006: 135). When the regime wanted to negotiate with party leaders and nonreligious political parties and was ready to make concessions, it could not find anyone with a solid popular base (Dadsetan 2003: 342$).{ }^{17}$ The shah had to directly face the movement, which had no smaller demand than his effective departure.

Amidst the fiercest opponents of the regime were the religious leaders. Traditionally they had had good relations with the state and were very well established in the society, with extensive prerogatives, properties and tax revenues. The shah wanted to put an end to this and had started to forbid taxation by religious institutions, to dispossess Islamic foundations, to control religious schools, etc. By doing this, he made himself powerful enemies: the clergy's "political center of gravity shift[ed] toward firm political opposition and, finally, revolution" (Skocpol 1994: 248). Ayatollah Khomeini was the most direct and charismatic of the shah's enemies, saying as early as the 1960s that "the Shah must go." In 1963, demonstrations in the holy town of Qom and Khomeini's speeches against the shah's landownership reforms were brutally repressed. This, in turn, incited spontaneous protests of sympathy all over the country, with several hundred demonstrators killed. Several months later-after having condemned the state's granting of diplomatic immunity to American military personnel in Iran-Khomeini was forced into exile, where he was able to develop and spread his ideas of an Islamic society and state: "In sum, Shi'a Islam was both organizationally and culturally crucial to the making of the Iranian Revolution against the Shah" (ibid.: 249). Through established structures for spreading ideas, the religious leaders could channel the dissatisfaction of the population into a political mass movement (Naficy 1993: 18). ${ }^{18}$

The events that triggered the revolution reveal the importance of religious structures, figures and rites in this historic event. On January 7, 1978, the Iranian newspaper Ettela'at published an article intended to defame Ruhollah Khomeini as Communist conspirator. This article, at-

17 Several previous incidents of unrest, such as the revolt of the June 5,1963, which was knocked down by security forces with between 5,000 to 10,000 deaths (Fürtig 1987: 62), had demonstrated the widespread dissatisfaction with the regime and the high level of solidarity with the clergy. These incidents had followed the incarceration of Ayatollah Khomeini.

18 Further, it was also relevant that the most holy sites of Shi'a Islam, Najaf and Kerbala, with the shrines of the first (Ali) and the third Imam (Hussein), were outside the Iranian border. This gave exiled religious political leaders-such as Khomeini-the opportunity to express their ideas more freely and to organize opposition (Steinbach 2005: 252). 
tributed to the Iranian secret service (SAVAK) and the information ministry, is considered to have been the decisive trigger for the Islamic Revolution. It had the converse effect of what was intended, and definitely made Khomeini the central figure of the opposition movement. The following day, demonstrations of solidarity in Qom were brutally repressed by the army; 300 demonstrators were wounded and 80 died. Subsequently, according to a 40-day rhythm (the time of mourning as practiced in Shi'a Islam), a spiral of protests began throughout the country, each time with more participants. The shah tried too late to appease the masses by making concessions to the opposition and was forced to leave the country. Two weeks later, on February 1, 1979, Ayatollah Khomeini came back from exile; established the system of the velayat-e faqih, the rule of the Islamic jurist; and himself stepped into the new function as religious leader.

Socioeconomic and demographic changes have been identified as important internal factors leading to the revolution, partly in relation to resource-specific conditions and partly not. It is important, however, to remember that the revolution started as "largely spontaneous collective action that proved unpredictable not only to Western analysts but even to its own leaders and participants" (Sadri/Sadri 2008: 63). One source of this energy came from the humiliation by external forces which Iran had endured in the past-used by the opposition movement to mobilize support-and the will of the people to take part in deciding upon their country's destiny. External interventions and other general international factors will be considered in the following discussion.

\section{d) International Non-resource-specific Context}

The revolution also needs to be understood in terms of its regional context and the global distribution of power. This has partly to do with the global oil market, but also goes beyond this to include power aspirations and value conflicts. Internal changes in other states and their activities in Iran did not fail to impact the Iranian population and its attitude towards foreign powers.

Relations with Neighboring Countries and Regional and Global Powers. Interventions from the outside have a long history in Iran. The accumulation of distrust towards foreign powers is therefore not unfounded. After the conquest of Iran by Alexander the Great, the Islamization of the country and the Arab influence linked to it, the bloody conquests by the Mongols, and the incorporation of parts of former Persia into the Ottoman Empire, others tried to gain a foothold in the country. ${ }^{19}$ At the beginning of the twentieth century it was Britain and Russia which were competing for spheres of influence in the region, treating Iran like a "buffer zone" between their empires. Their influence was so strong that they were able to convince Reza Khan, then commander of the Cossack Brigade, who had overthrown the weakened Qajar regime, to maintain a monarchical system and even become an emperor. During the

19 It is not forgotten here that the Persian Empire also fought to conquer and dominate the whole region. 
World War II, foreign powers put an end to the reign of Reza Shah Pahlavi, accusing him of having too close a relationship with the German Reich, and replaced him with his son, Mohammad Reza, in 1941. Following the coup of 1953, the US began interfering to a great extent in Iran's domestic affairs. But as Iran was one of the few areas of the world that was part of the spheres of influence of both superpowers (Pelletiere 1992:17), this interference was mostly behind the scenes.

While the Allies had pressured Mohammad Reza Shah in the last years of World War II to make his regime more liberal and democratic than his father's, they lost their interest in public participation with the emergence of Mossadegh and the threat he posed to the interests of the Western oil companies. After Mossadegh was deposed, Western governments and corporations again preferred "a centralized government under a pro-Western ruler who would not again allow into power a regime that might threaten economic and political relations with the West" (Keddie 2006: 133). It was not so much a Communist threat that kept them so preoccupied; the biggest fear of the Western countries was "a non-Communist nationalist government taking over, in defiance of (...) economic and strategic resources important to the West. Occasional Western pressures to mitigate his dictatorship, as in the early 1960s, were finessed by the shah, who probably knew where the real priorities of American governmental and business interests lay" (ibid.).

The shah knew perfectly well that playing the role of a "policeman on the Gulf" for an America that was very much preoccupied by Vietnam and the Cold War "gave him leverage" (Pollack 2004: 104). He thought that the US would stop instructing him on how to run Iran if they really wanted him to defend American interests in the Persian Gulf. The Nixon administration left him in peace, indeed, "virtually eliminating all criticism of Iranian human rights abuses, resisting any effort to convince the shah to reform his political and economic system, refraining from passing judgment on the White Revolution and other Iranian internal policies, and essentially leaving it up to the shah to run Iran's affairs" (Pollack 2004: 104). Criticism only emerged in the American press with the increasing push for oil-price increases by the shah during the late 1970s during the presidency of Gerald Ford (Cooper 2008). Even US president Jimmy Carter, who declared human rights the "soul of our foreign policy," was rather indulgent. The shah had feared more intrusion and pressure from the new US president to move towards political liberalization, something that he tried to pre-empt with some reforms and a slight softening of his police state (Pollack 2004: 121).

The US indulgence may have been linked to the administration's hope of getting the shah's help in bargaining for lower oil prices in OPEC, and of keeping the electronic intelligence collection sites in northern Iraq, which were used to collect information about the USSR (ibid.: 122). President Carter and his wife's visit to Iran in January 1978, which saw the president praising the shah in various speeches and his famous New Year's Eve toast that Iran was "an island of stability in a turbulent corner of the world," had an effect. It led to the total disappointment of the Iranian opposition movement, which had put great hopes in the 
Carter presidency, and the movement's feeling of having been deeply betrayed (ibid.: 124ff.). Immediately afterwards, Khomeini called Carter a hypocrite with a very malleable understanding of human rights, something which could have been a key reason for the publication of the defamatory article about Khomeini that, as described above, was the main trigger of the revolutionary demonstrations.

Interdependence of the Country. Unlike his father, Mohammad Reza greatly increased Iran's dependency on the West, which was profitable for Western and especially American companies (Keddie 2006: 133f.). The shah increasingly decided to follow Western patterns of economic development, partly because of the boycott of oil exports by the international community and the restriction of foreign aid after the nationalization of oil assets in 1951.

As a result of the rising oil prices, the shah was recycling some of Iran's oil revenue back into the so-called military-industrial complex in the United States (Fayazmanesh 2008: 12), making the United States even more interested in a well-equipped Iranian defense and repression apparatus, as it was clearly drawing profits from these sales. The agrarian reform of the 1960s was strongly inspired by the US, and enabled it to attain new markets for US agroalimentary products (Fürtig 1987: 27). ${ }^{20}$ This makes clear the extent to which US economic interests other than oil were also satisfied by its rising influence of the region. The whole region was and remains of great interest to the different global powers not only because of its oil resources but also-and this is often neglected by theory-because of its considerable population size and, therefore, important markets. ${ }^{21}$

The clashes with external interests and their methods of intervention, described above, deeply marked Iran's collective psyche. The pride of the Iranians was hurt by the continuing interference of foreign powers, even if the country never was fully colonized. In particular, the coup against Prime Minister Mossadegh was, seen from today's vantage point, a direct source of the later revolutionary energy in Iran and the strong grievances against the West (Steinbach 2007: 4). In the coup's aftermath, the US supported the shah's return and negotiated favorable conditions for oil purchases and access to the Iranian market. The impact of this coup cannot be overestimated. The vivid memories of this foreign intrusion clashed with the national pride of Iranians and were, as described, later mobilized for resistance. It definitely changed the image of the US held by the Iranian population and its intelligentsia (Sheikhzadegan 2003: 129f.). The general distrust towards the US was further deepened by public opinion on the cruel war the US fought in Vietnam. ${ }^{22}$ It found its expression in the anti-American rhetoric during the revolution and hostile reactions to anything that was linked to the US. When the shah was admitted to the United States for medical treatment on October 22, 1979, many Iranians interpreted it as evidence that the Carter administration was

\footnotetext{
20 While Iran was a self-sufficient nation until the 1960s, it became more and more dependent on food imports. In 1978, 80 percent of its food came from outside the country (Fürtig 1987: 72).

21 Author's interview in Tehran, May 14, 2008.

22 Author's interview in Tehran, April 29, 2008.
} 
plotting to bring him back to power. Only two weeks later, the US Embassy in Tehran was seized by militant students, who held the employees hostage for 444 days. This led to the freezing of US-Iranian relations.

General Conflict Potential in the Region. Khomeini derived the necessity of establishing a theocratic state from the danger of interference from Western or Israeli powers. Of utmost relevance in this context is therefore the Arab-Israeli conflict. The foundation of Israel in 1948 and the resulting discrimination against the Palestinian Arabs was from the perspective of the Arabs and Muslims of the region a fundamental violation of their rights and dignity. The expulsion of the Palestinians by Israeli troops soon became a deeply rooted wound in the collective conscience of Islamic nations (Sheikhzadegan 2003: 125). The modernists in the Arab world were shocked to the core by this blatant partiality on the part of the West. From now on the West was not perceived as a model of society to be emulated anymore; rather, it seemed to be the incarnation of the unjust (ibid.: 124). The rise of socialist Arab leaders was one of the consequences of this, but the later defeat of the Arabs in their war against Israel in 1967 also led to a decisive loss of legitimacy for these new ideologies. Neither modernism, in the sense of the imitation of the Western societal model, nor socialist nationalism could bring dignity and integrity back to the Muslims. The argument of the Islamists that the reason for the misery in the Islamic world was to be found in the loss of the real faith, as proclaimed by the politicized Iranian clerics, found an increasing audience in the Muslim societies. The shah was friendly towards Israel, but large parts of the Iranian society identified themselves with the Arab cause and criticized the Iranian regime for its indifference towards the Arab states. Evidence of aid to SAVAK from the American CIA and the Israeli Mossad clearly added to the resentment against the countries involved (Keddie 2006: 134).

The external context thus highly impacted the occurrence of the revolution and the very nature of the Islamic Republic. ${ }^{23}$ During the revolution, the connection between the anti-regime movement in Iran and the jihad of the Muslims against Israel remained an omnipresent topic, which was also one of the few common denominators of the different factions of the movement (Sheikhzadegan 2003: 133). From his French exile, Khomeini commented on the departure of the shah in January 1979 that it was not "the final victory"; more important than the abdication of the Pahlavi dynasty was "the end of foreign domination" (Time, January $29,1979)$. This comment demonstrates that this was a goal of the revolutionary movement as a whole. Khomeini's interpretation of Shi'a Islam was thus a new approach, integrating anticolonial resistance.

\subsection{Interplay of Contextual Conditions}

So, why did the shah fall at all (and why at the particular moment that he did)? The collapse of his regime was due to a combination of circumstances which had increasingly weakened

23 A separate, but pertinent, question is why Islamic revolutions did not succeed in any Arab country. 
it. His failed modernization policy, the heavy dependency of the whole regime on the quality of his decisions, and his brutal repression, which undermined the legitimacy of his system even further, can be considered as being his own responsibility. Further developments, such as demographic changes (urbanization and population growth) and the rising power of the religious elites, were only partly within his control. His agrarian reform clearly contributed to the accelerated urbanization and the economic hardship experienced by many people. But even before he executed these policies, he already had many opponents within the population-even more so as he was only brought back to the head of the state by foreign powers after the putsch against the popular prime minister.

Iran's oil wealth - the independent variable of this study-was, as has been shown, not the weakest factor contributing to the revolution; however, it is explanatory only when linked to other resource-specific factors determining the impact of this wealth and to non-resourcespecific factors. This is sometimes not adequately acknowledged in conventional theories and theoretical approaches.

Oil, and the income it generated, was indeed a motive for internal forces to maintain or, probably, strive to obtain power. But it was to an even greater extent an opportunity or instrument for the shah's regime to stay in power-though it also turned out to be an effective instrument for the opposition to use to weaken the regime. The main impact of oil, however, was indirect. It heavily fuelled the political and economic crisis that developed prior to the revolution, but it was not the only reason for it. Many factors contributed to this crisis, but it was particularly the interplay of these conditions and the causal mechanisms through which they worked that made the Iranian Revolution possible. Oil played a role in stabilizing the Pahlavi regime for a long time and contributed to widening the gap between the government and the society - until this gap reached an unsustainable threshold. It has become clear here that it was actually the dependence on oil income by both the regime and the entire economy of the country rather than the wealth in itself that made the political system highly vulnerable to price drops or reductions in demand. In addition to these external resource-specific reasons, the fact that the Iranian oil workers could become relevant political actors by cutting the Iranian oil supply during their strike was also of high relevance. Other internal resourcespecific causes included the particular uses made of the oil money and their devastating "Dutch (or "Iranian") Disease" effects. Yet oil was far from being the only or the main reason for this turn in history. It was through the combination of its impacts with the other, more deeply rooted contextual conditions such as the culture and the collective memories of the society that it could unfold this energy.

Only in combination with other factors not directly related to oil or income deriving from this sector could a crisis of this scale could occur. As very relevant non-resource-specific contextual conditions, this paper has identified the legitimacy of institutions, the behavior of the elites, political ideas and ideologies, and economic and demographic changes. On the one hand, the shah's modernization efforts initiated identity conflicts, which people sometimes 
tried to resolve with an intensifying religiosity. On the other hand, national feelings and the wish to participate in politics drove many opposition forces to challenge the regime, and this drive then spilled over to the poorer groups among the population. The specific characteristics of Shi'a Islam, its valuing of heroic martyrs, dying for their belief and community, as well as its organizational structure, contributed to the success of the clerical opposition, who, furthermore, had good access to large parts of Iranian society and a good overview of their miserable social situation. The poor socioeconomic status of large parts of the society was probably the most important condition causing revolutionary ideas to eventually fall on fertile ground. More diffuse impacts very probably resulted from the general political culture, the behavior of the elites, and the general international context, all of which are more difficult to test.

Resource-specific factors indeed had an impact on those cultural and social conditions and the general socioeconomic situation. Even if the attempt at rapid modernization was the shah's personal choice (and error), it would not have been possible without the huge oil revenues flowing into the country. The effects of the economic crisis were also undeniably linked with oil dependency rather than oil wealth. After a period of oil-driven economic boom, the Iranian economy suddenly slowed down in 1977, putting an abrupt end to many Iranians' hopes of acquiring more personal wealth. The inequality within and disappointment among Iranian society, already stark before the oil boom, thereby clearly intensified. Perhaps it was the fresh frustration resulting the sudden destruction of dreams and hopes that provided the energy for this mass upheaval. But was this frustration due only to a rentier effect, alienating a government from its population? Was it destiny that, due to its oil wealth, democracy - and a diversified economy - could not develop in Iran and that violence and protest remained the sole interaction between governor and governed? The shah miscalculated the effects of many of his steps - the appropriateness of his development measures and the effectiveness of his repression - and he lost the chance to realize his goal of a modern, industrialized Iran. He also did not see the danger of the brutality he exercised through his secret and security forces when fighting the opposition and killing demonstrators. The distance between him and his people was more than just economic; he did not understand them culturally. As he was its keystone, the entire regime broke down as a result of his and his advisors' failure.

But it was not only the government's decisions (and its use of the oil income) that affected the social and economic situation in Iran. External interests and interference, as we have seen, had an undeniable impact on reforms in Iran and thus their political and socioeconomic consequences. The putsch of 1953 and, much later, the gradual distancing of the US from the shah when he pushed for high oil prices are of high relevance when tracing the consolidation and disintegration of his power. The motive driving these external powers was very much the Iranian oil wealth; they wanted to keep this under their control. For a long time the shah had counted on his good relations with the US and other Western powers to sustain his 
power, but it was these very relations that caused an even greater rift between the shah and his people.

Looking at the Iranian Revolution in terms of the international context places the resource argument even more in the center, as the industrialized countries were openly worrying about the stability (in their favor) in the region, which was (and still is) the main oil supplier to the world market. Interference from outside the country led to an accumulation of grievances and distrust towards foreign powers and, together with other values rooted in the collective psyche of Iranians, explains a big part of the passion that became evident in the events leading up to the revolution.

\section{Summary and Conclusion}

The starting point of this analysis was the observation that the Iranian revolution still represents a puzzle for academics, and the hypothesis that it cannot be explained by a single theoretical approach. The aim of the present study has been to scrutinize whether the conventional theoretical approaches analyzing the impact of resource wealth on states can explain the level of violence linked to the Iranian Revolution. The supposed and subsequently diagnosed limits of the resource curse approach and rentier state theory have been complemented by a set of contextual conditions. Neither culturalist nor resource-centered approaches could have predicted what happened in 1979. To identify the revolution as a sign of "deviance" is not a solution either, as the various theories all have a certain amount of explanatory power. When they are combined, the process preceding this regime change becomes clearer. The context approach-which assumes that "context matters" - is useful for analyzing this case as it acknowledges that many factors play a role and that their interplay in particular is among the root causes of violence. While the revolution was not characterized by large-scale violence, it was, however, very much characterized by public reactions against the violence exercised by the central power. This, in combination with the remaining theoretical puzzle, was one of the reasons for choosing this case.

In the case of Iran, this paper has stated that oil wealth was indeed a factor in the emergence of the different forms of violence, but that most of the time the link was indirect. Oil had, on the one hand, a major impact on the government budget and thus the government's ability to interfere in the economy and society. On the other hand, oil had, to a large extent, an impact on the entire economy. This included not only positive effects, such as growth and employment generation, but also negative ones, such as "Dutch/Iranian Disease" or inflationary effects. These impacts are considered here to have been of utmost importance in the evergrowing protests leading up to the revolution.

For a comprehensive understanding of oil-exporting states, consideration of the external context is of significant relevance. While the resource curse approach and especially the rentier state theory focus mainly on internal developments and dynamics, I have here proposed the 
integration of the external context and have found evidence that "geopolitics matter." The high stakes in the Middle Eastern region for European industrialized states-both for superpowers during the Cold War and for all major powers today-explains the high level of attention this region receives in times of both peace and conflict. Without Iran's bad experiences with Western and Russian interference, the Islamic Revolution would probably not have taken place. It is not my purpose here to blame foreign powers as being solely responsible for violence-due to their sometimes rough methods of interfering and defending their interests-but it is necessary to point out these mechanisms in order to overcome widespread opinions and the simplistic view of the theories presented. In a highly globalized world with very penetrable borders (at least for resources, goods, and money), it is impossible to distinctly differentiate between the internal and external factors causing conflict and instability. Indeed, without considering the complex linkages between the many contextual conditions present in a country, it is impossible to really understand the outbreak and maintenance of violence- or to find a solution for resolving conflicts and, maybe, derive some lessons for the future. 


\section{References}

Abrahamian, Ervand (1982): Iran Between Two Revolutions. New Jersey: Princeton University Press.

Amnesty International (1990): Iran, Violations of Human Rights, 1987-1990. http://www.amne sty.org/en/library/asset/MDE13/021/1990/en/5c32759d-ee5e-11dd-9381-bdd29f83d3a8/mde 130211990en.html.

Amuzegar, Jahangir (1991): The Dynamics of the Iranian Revolution. The Pahlavi's Triumph and Tragedy. New York: State University of New York Press.

Asghari, Reza M. (1998): Iranian Disease und Institutional Gap. Frankfurt: Peter Lang.

Auty, Richard (1993): Sustaining Development in Mineral Economies. The Resource Curse Thesis. London: Routledge.

Bamberg, J.H. (1994): The History of the British Petroleum Company, vol. 2. Cambridge: Cambridge University Press.

Basedau, Matthias (2005): Context Matters - Rethinking the Resource Curse in sub-Saharan Africa, Working Papers Global and Area Studies, Working Paper Nr. 1, edited by the German Overseas Institute (DÜI). Hamburg: DÜI.

Basedau, Matthias / Lacher, Wolfram (2006): A Paradox of Plenty? Rent Distribution and Political Stability in Oil States, GIGA-Working Paper Nr. 20. Hamburg: GIGA.

Basedau, Matthias / Lay, Jann (2009): Resource Curse or Rentier Peace? The Ambiguous Effects of Oil Wealth and Oil Dependence on Violent Conflict, in: Journal of Peace Research.

Basedau, Matthias / Mehler, Andreas (2003): African Resources and War, in: Internationale Politik, Transatlantic Edition, 4, 3, p. 95-100.

Beblawi, Hazem / Luciani, Giacomo (eds.) (1987): The Rentier State. London: Croom Helm.

Beck, Martin (2007): Der Rentierstaats-Ansatz und das Problem abweichender Fälle, in: Zeitschrift für Internationale Beziehungen, vol. 1, p. 43-70.

Boschini, Anne D. / Petterson, Jan / Roine, Jesper (2007): Resource Curse or Not: A Question of Appropriability, in: Scandinavian Journal of Economics, vol. 109, 3, p. 593-617.

BP - British Petroleum (2009): Statistical Review of World Energy 2009.

Brunnschweiler, Christa N. / Bulte, Erwin H. (2006): The Resource Curse Revisited and Revised: A Tale of Paradoxes and Red Herrings, Economics Working Paper Series no. 06/61. Zürich: ETH.

Brunnschweiler, Christa / Bulte, Erwin (2008): Natural Resources and Violent Conflict: Resource Abundance, Dependence and the Onset of Civil Wars, Economics Working Paper Series no. 08/78. Zürich: ETH.

Collier, Paul / Hoeffler, Anke (2004): Greed and grievance in civil war, in: Oxford Economic Papers 56, p. 563-595. 
Collier, Paul / Hoeffler, Anke (2002): On the incidence of civil war in Africa, in: Journal of Conflict Resolution, vol. 46/1.

Collier, Paul / Hoeffler, Anke (2001): Greed and Grievance in Civil War. Washington, DC: World Bank.

Collier, Paul / Hoeffler, Anke (1998): On Economic Causes of Civil War, in: Oxford Economic Papers, Oxford University Press, vol. 50, 4, p. 563-73.

Cooper, Andrew Scott (2008): Showdown at Doha: The Secret Oil Deal That Helped Sink the Shah of Iran, in: Middle East Journal, vol. 62, 4, p. 567-591.

Dadsetan, Mohammad Mehdi (2003): L'autoritarisme du pouvoir politique et le "sousdéveloppement" économique en Iran. Thèse de doctorat de l’Université en changement social/Lille, in: https://iris.univ-lille1.fr/dspace/bitstream/1908/422/2/50377-2003-11-12.pdf (01.10.2009).

De Soysa, Indra (2002): Paradise is a Bazaar? Greed, Creed, and Governance in Civil War, 1989-99, in: Journal of Peace Research, vol. 39/4, p. 395-416.

De Soysa, Indra / Neumayer, Eric (2007): Resource Wealth and the Risk of Civil War Onset: Results from a New Dataset of Natural Resource Rents, 1970-1999, in: Conflict Management and Peace Science, vol. 24/3, p. 201-218.

Di John, Jonathan (2007): Oil Abundance and Violent Political Conflict: A Critical Assessment, in: Journal of Development Studies, vol. 43/6, p. 961-986.

Ebert, Hans-Georg / Fürtig, Henner / Müller, Hans-Georg (1987): Die Islamische Republik Iran. Edited by Günter Barthel. Cologne: Pahl-Rugenstein Verlag.

Ehsani, Kaveh (2005): Oil Boom \& Bust. Social engineering and the contradictions of modernization in Khuzestan's oil company towns, Abadan and masjed-Soleyman, Februar. http://www.iranian.com/Abadan/2005/February/Khuzestan/notes.html (10.10.2008)

Energy Information Administration (EIA) (2008): OPEC Revenues Fact Sheet. Country Analysis Briefs. http://www.eia.doe.gov/emeu/cabs/OPEC_Revenues/pdf.pdf (18.3.2009)

Fayazmanesh, Sasan (2008): The United States and Iran. Sanctions, wars and the policy of dual containment. New York: Routledge.

Fürtig, Henner (1987): Die antimonarchistische Volksrevolution - eine historische Tat der iranischen Volksmassen, in: Ebert, Hans-Georg / Fürtig, Henner / Müller, Hans-Georg (1987): Die Islamische Republik Iran. Edited by Günter Barthel. Cologne: Pahl-Rugenstein Verlag.

Gheissari, Ali / Nasr, Valil (2006): Democracy in Iran. History and the Quest for Liberty. Oxford: Oxford University Press.

Herb, Michael (2005): No Representation without Taxation? Rents, Development and Democracy, in: Comparative Politics, vol. 37/3, p. 297-317. 
Hippler, Jochen (2006): War, Repression, Terrorism. Political Violence and Civilisation in Western and Muslim Societies, in: Krieg, Repression, Terrorismus. Politische Gewalt und Zivilisation in westlichen und muslimischen Gesellschaften. Stuttgart: Institut für Auslandsbeziehungen.

Huntington, Samuel P. (1971): The City-country Gap: Urban Breakthrough and Green Uprising, in: Finkle, Jason L. / Gable, Richard W. (eds.): Political Development and Social Change. New York: Wiley, p. 227-231.

Kapuscinski, Ryszard (2006): Shah of Shahs. London: Penguin Books.

Karl, Terry Lynn (1997): Oil Booms and Petro-states. Berkeley: University of California Press.

Karshenas, Massoud / Hakimian, Hassan (2008): Managing oil resources and economic diversification in Iran, in: Katouzian, Homa / Shahidi, Hossein (ed.): Iran in the $21^{\text {st }}$ Century. Politics, Economics \& Conflict. London and New York: Routledge, p. 194-216.

Keddie, Nikki R. (2006): Roots and Results of Revolution: An Interpretive History of Modern Iran. With a section by Yann Richard. New Haven and London: Yale University Press.

Kinzer, Stephen (2008): All the Shah's men: An American Coup and the Roots of Middle Eastern Terror. Hoboken, N.J.: John Wiley \& Sons.

Kleveman, Lutz (2004): The New Great Game. Blood and Oil in Central Asia. New York: Atlantic Books.

Le Billon, Philippe (2001): The political ecology of war: natural resources and armed conflicts, in: Political Geography, vol. 20/5, p. 561-584.

Luciani, Giacomo (1987): Allocation vs. Production States: A Theoretical Framework, in: Beblawi, Hazem / Luciani, Giacomo (eds.): The Rentier State. London: Croom Helm, p. 6382.

Mahdavy, Hossein (1970): The patterns and problems of economic development in rentier states, in: M.A. Cook (ed.), Studies in the Economic History of the Middle East. London: Oxford University Press.

Naficy, Mehdy (1993): Klerus, Basar und die iranische Revolution. Hamburg: Deutsches Orient-Institut.

Najmabadi, Afsaneh (1987): Depoliticisation of a Rentier State: The Case of Pahlavi Iran, in: Beblawi, Hazem / Luciani, Giacomo (ed.): The Rentier State. London: Croom Helm.

Nathan, Laurie (2005): 'The Frightful Inadequacy of Most of The Statistics': A Critique of Collier and Hoeffler on Causes of Civil War. London: Crisis States Research Center, Discussion Paper No. 11.

Pelletiere, Stephen C. (1992): The Iran-Iraq War. Chaos in a Vacuum. New York: Prager.

Pollack, Kenneth M. (2004): The Persian Puzzle. The Conflict between Iran and America. New York: Random House. 
Razavi, Hossein / Vakil, Firouz (1984): The Political Environment of Economic Planning in Iran, 1971-1983: From Monarchy to Islamic Republic. Boulder and London: Westview Press.

Ross, Michael L. (2006): A Closer Look at Oil, Diamonds, and Civil War, in: Annual Review of Political Science, vol. 9, p. 265-300.

Ross, Michael L. (2004): What Do We Know about Natural Resources and Civil War?, in: Journal of Peace Research, vol. 41/3, p. 337-356.

Rosser, Andrew (2006): The Political Economy of the Resource Curse: A Literature Survey. Brighton: IDS Institute of Development Studies. Working Paper 268.

Sachs, Jeffery D. / Warner, Andrew M. (1995): Natural Resource Abundance and Economic Growth. NBER Working Paper, no. 5398. Cambridge: National Bureau of Economic Research.

Sachs, Jeffery D. / Warner, Andrew M. (2001): The curse of natural resources, in: European Economic Review, Elsevier, vol. 45/4-6, p. 827-838.

Sadri, Mahmoud / Sadri, Ahmad (2008): Three faces of dissent. Cognitive, expressive and traditionalist discourses of discontent in contemporary Iran, in: Katouzian, Homa / Shahidi, Hossein (ed.): Iran in the $21^{\text {st }}$ century. Politics, economics \& conflict. Abingdon: Routledge.

Sheikhzadegan, Amir (2003): Der Griff des politischen Islam zur Macht. Iran und Algerien im Vergleich. Europäische Hochschulschriften. Bern: Peter Lang.

Skocpol, Theda (1994): Rentier state and Shi'a Islam in the Iranian Revolution, in: Social Revolution in the Modern World. New York: Cambridge University Press, p. 240-258.

Skocpol, Theda (1979): States and Social Revolutions: A Comparative Analysis of France, Russia and China. Cambridge: Cambridge University Press.

Smith, Benjamin (2004): Oil Wealth and Regime Survival in the Developing World, 1960-1999, in: American Journal of Political Science, vol. 48/2, p. 232-246.

Steinbach, Udo (2005): Iran, in: Ende, Werner / Steinbach, Udo (ed.): Der Islam in der Gegenwart. Bonn: Bundeszentrale für politische Bildung, p. 246-263.

Steinbach, Udo (2007): Die widerspruchsvolle „Republik“ - Iran auf dem Weg zu einer regionalen Vormacht?. FES Analyse, Berlin: FES.

Time (1979): IRAN: The Shah Takes His Leave. January 29th, 1979, in: http://www.time.com/ time/printout/0,8816,912319,00.html (1.10.2009)

Urdal, Henrik (2004): The Devil in the Demographics: The Effect of Youth Bulges on Domestic Armed Conflict, 1950-2000, Conflict Prevention \& Reconstruction. Social Development Papers, Nr. 14. 
Williamson, John (2008): Exchange rate economics. Washington, DC: Peterson Inst. for Internat. Economics.

Yergin, Daniel (2003): The Prize. The Epic Quest for Oil, Money \& Power. New York: Free Press. 


\section{G

\section{Recent Issues}

No 112 Annegret Mähler: Oil in Venezuela: Triggering Violence or Ensuring Stability? A Contextsensitive Analysis of the Ambivalent Impact of Resource Abundance; October 2009

No 111 Martin Beck: Oil-rent Boom in Iran?; October 2009

No 110 Juliane Brach and Robert Kappel: Global Value Chains, Technology Transfer and Local Firm Upgrading in Non-OECD Countries; October 2009

No 109 Heinz Jockers, Dirk Kohnert and Paul Nugent: The Successful Ghana Election of 2008 - a Convenient Myth? Ethnicity in Ghana's Elections Revisited; September 2009

No 108 Sebastian Huhn: The Culture of Fear and Control in Costa Rica (II): The Talk of Crime and Social Changes; September 2009

No 107 David Shim: Shrimp amongst Whales? Assessing South Korea's Regional-power Status; August 2009

No 106 Günter Schucher: Where Minds Meet: The "Professionalization" of Cross-Strait Academic Exchange; August 2009

No 105 Alexander Stroh: The Effects of Electoral Institutions in Rwanda: Why Proportional Representation Supports the Authoritarian Regime; July 2009

No 104 Sebastian Huhn: The Culture of Fear and Control in Costa Rica (I): Crime Statistics and Law Enforcement; July 2009

No 103 Günter Schucher: Liberalisierung in Zeiten der Instabilität: Spielräume unkonventioneller Partizipation im autoritären Regime der VR China [Liberalization in Times of Instability: Margins of Unconventional Participation in Chinese Authoritarianism]; June 2009

No 102 Leslie Wehner: Power, Governance, and Ideas in Chile's Free Trade Agreement Policy; May 2009

No 101 Sebastian Huhn: Contested Cornerstones of Nonviolent National Self-Perception in Costa Rica: A Historical Approach; May 2009

No 100 Matthias Basedau, Alexander Stroh: Ethnicity and Party Systems in Francophone SubSaharan Africa; May 2009

No 99 Christian von Soest: Stagnation of a "Miracle": Botswana's Governance Record Revisited; April 2009

All GIGA Working Papers are available free of charge at www.giga-hamburg.de/workingpapers. For any requests please contact: workingpapers@giga-hamburg.de.

Editor of the Working Paper Series: Martin Beck 